\title{
ANALISIS STRUKTUR BIAYA USAHA TANI BAWANG MERAH BERDASARKAN TUJUAN PASAR MENGGUNAKAN METODE COBB-DOUGLAS STOCHASTIC FRONTIER PRODUCTION FUNCTION
}

\author{
Denny Andrelader Razzianto1) \\ Eti Suminartika1) \\ Trisna Insan Noor ${ }^{1}$ ) \\ Kalfin $\left.2^{*}\right)$ \\ 1)Fakultas Pertanian, Universitas Padjadjaran, Indonesia \\ 2)Doctor Program of Mathematics, Faculty of Mathematics and Natural Sciences, Universitas \\ Padjadjaran, Indonesia \\ e-mail: kalfin17001@mail.unpad.ac.id)
}

\begin{abstract}
Shallots (Allium ascolonicum, $L$ ) are high-value horticultural commodities that need to be developed as strategic commodities in addition to rice, red chilies, chicken and beef. In addition, shallots have a high economic value and are a commodity used in the processing of various foods. This causes the consumption or demand for shallots to increase along with the increase in population. Therefore, this study aims to analyze the cost structure of shallot farming with the aim of the market for consumption and for the fried onion industry in Majalengka District, Majalengka Regency. The method used to estimate the Cobb-Douglas production function is the stochastic frontier method, with the sampling technique used in this study, namely proportional random sampling. Based on the results of the analysis, it is found that the cost structure of shallot farming for the purpose of the fried onion industry and consumption is feasible when viewed from the $R / C$ ratio of the average agricultural destination for the fried onion industry with a value of 1.25 and for shallot farming for consumption purposes with a value of 1.30 , where $R / C>1$. Meanwhile, the production factor that requires the largest cost for shallot farming, the purpose of the fried onion industry, is the cost of seeds / seeds with a value of IDR. 13,548,300 and the largest cost used by shallot farming for consumption purposes is the cost of seeds / seedlings of IDR. $30,870,148.94$. This is due to the need for seeds for an area of one hectare, the price of seeds is quite high due to the limited number of seeds / seeds needed so that the price of seeds increases and the factor of chaos also affects the limited number of seeds needed. The results of this study are expected to be a reference for local governments in developing agriculture, especially in the shallot tabi business sector.
\end{abstract}

Keywords: shallots, ratio, cost structure, stochastic frontier method

\begin{abstract}
ABSTRAK
Bawang merah (Allium ascolonicum, L) merupakan komoditas hortikultura bernilai tinggi yang perlu dikembangkan sebagai komoditas strategis selain beras, cabai merah, daging ayam, dan daging sapi. Selain itu, bawang merah memiliki nilai ekonomis yang tinggi dan komoditas yang digunakan dalam pengolahan berbagai makanan. Hal tersebut
\end{abstract}


menyebabkan konsumsi atau permintaan bawang merah meningkat seiring dengan peningkatan jumlah penduduk. Oleh karena itu, pada penelitian ini bertujuan menganalisis struktur biaya usahatani bawang merah dengan tujuan pasar untuk konsumsi dan untuk industri bawang goreng di Kecamatan Majalengka Kabupaten Majalengka. Metode yang digunakan untuk menduga fungsi produksi Cobb-Douglas adalah metode stochastic frontier, dengan teknik penarikan sampel yang dilaksanakan pada penelitian ini yaitu proporsional random sampling. Berdasarkan hasil analisis diperoleh bahwa struktur biaya usahatani bawang merah tujuan industri bawang goreng dan konsumsi layak diusahakan bila dilihat dari $R / C$ rasio rata-rata usahatani tujuan industri bawang goreng dengan nilai 1,25 dan untuk usahatani bawang merah tujuan Konsumsi dengan nilai sebesar 1,30, dengan R/C $>1$. Sedangkan faktor produksi yang membutuhkan biaya terbesar untuk usaha tani bawang merah tujuan industri bawang goreng yaitu biaya bibit/benih dengan nilai sebesar Rp.13.548.300 dan biaya terbesar yang digunakan usahatani bawang merah tujuan konsumsi yaitu biaya benih/bibit sebesar Rp.30.870.148,94. Hal ini disebabkan kebutuhan bibit untuk luasan satu hektar, harga bibit yang cukup tinggi karena keterbatasaan jumlah bibit/benih yang dibutuhkan sehingga harga bibit meningkat dan faktor kemaurau juga pengaruh terhadap keterbatasan bibit yang dibutuhkan. Hasil penelitian ini diharapkan dapat menjadi referensi bagi pemerintah daerah dalam mengembangkan pertanian khususnya pada sector usaha tabi bawang merah.

Kata kunci: bawang merah, rasio, struktur biaya, metode stochastic frontier

Permintaan komoditas bawang merah di Indonesia sangat tinggi tetapi dari permintaan tersebut faktor tujuan pasar yang menentukan. Tujuan pasar tersebut antara lain untuk konsumsi rumah tangga ada pula untuk kebutuhan industri seperti industri bawang goreng (Razzianto et al., 2020). Kombinasi penggunaan input-input produksi, tingkat efisiensi usahatani bawang merah akan dipengaruhi oleh tujuan pasar bawang merah. Ketersediaan bawang merah yang tidak merata di pasaran disebabkan oleh produksi bawang merah yang bersifat musiman. Di Kabupaten Majalengka pada umumnya musim tanam bawang merah (in season) dilakukan di musim kemarau pada bulan Februari sampai dengan bulan September (Apriani, 2011). Pada musim hujan petani jarang sekali melakukan penanaman bawang merah yaitu pada bulan Oktober-Januari. Petani bawang merah di Kabupaten Majalengka tidak melakukan penanaman pada musim hujan dikarenakan pengaruh curah hujan yang tinggi akan menyebabkan terjadinya kerusakan fisik pada daun bawang merah dan busuk umbi. Hal ini akan memberikan dampak terhadap kehilangan hasil panen pada musim hujan.

Perencanaan kawasan pertanian berbasis mitigasi bencana alam perlu dilakukan (Kalfin et al., 2021). Oleh sebab itu, penanaman bawang merah lebih banyak dilakukan pada musim kemarau. Musim kemarau air sering merupakan faktor pembatas bagi pertumbuhan tanaman, terutama di daerah kering (Padjung et al., 2020). Penanaman bawang merah di musim kemarau dibantu dengan irigasi dapat dengan frekuensi dua kali sehari dapat meningkatkan bobot panen bawang merah. (Fauzan et al., 2016). Usahatani bawang merah membutuhkan biaya per satuan luas lahan yang relatif tinggi khususnya untuk upah tenaga kerja dan sarana produksi. Kabupaten Majalengka pengeluaran biaya untuk sarana produksi menempati urutan pertama dengan proporsi biaya berkisar antara $21.60 \%$ $34.50 \%$ dibandingkan biaya untuk penggunaan tenaga kerja sebesar 16.3-32.9 persen terhadap total 
penerimaan. Tingginya biaya sarana produksi, terutama disebabkan oleh tingginya harga bibit (Rachman et al., 2004; Rahmadona, and Fariyanti, 2017). Rata-rata biaya produksi yang dikeluarkan oleh petani bawang merah di Kabupaten Majalengka sebesar Rp.10.710,53 kg-1 (Apriani, 2011).

Peningkatan kualitas produk, diperlukan sentuhan teknologi dalam agroprossesing, dimana penggunaan teknologi merupakan hal yang sangat penting dalam mendapatkan kualitan produksi yang lebig baik. Penanganan proses secara manual, selain memerlukan waktu yang lama juga tidak efisien (Tian et al., 2020). Dalam usaha pengolahan bawang goreng, teknologi yang dibutuhkan meliputi subsistem, mulai dari agroproduksi fase budidaya (On Farm) untuk menjamin suplai bahan baku hingga agroprossesing yang meliputi pengupasan, pengirisan, penggorengan, penirisan sampai pengemasan (Off Farm) (Salingkat, 2017). Upaya peningkatan pemasaran komoditas yang sesuai pemasaran perlu dilakukan (Setiawan et al., 2021; Alfarizy et al., 2021). Bawang merah yang disebutkan sebagai komoditas yang digunakan dalam pengolahan berbagai makanan, diantaranya sebagai sayuran konsumsi masyarakat dan untuk kebutuhan industri olahan bawang merah, contohnya adalah bawang goreng yang lebih tahan lama dibanding bawang mentah, tepung bawang dan lain-lain. Industri bawang goreng pastinya membutuhkan bawang merah sebagai bahan dasar utama dan kebutuhan bahan dasar utama. Tujuan pengembangan agribisnis bawang merah mencakup: (a) Menyediakan benih varietas unggul bawang merah kualitas impor sebagai salah satu upaya substitusi (pengurangan ketergantungan terhadap pasokan impor); (b) Meningkatkan produksi bawang merah rata-rata 5.24\% per tahun selama periode 2005-2010; (c) Mengembangkan industri benih bawang merah dalam rangka menjaga kontinuitas pasokan benih bermutu; serta (d) Mengembangkan diversifikasi produk bawang merah dalam upaya peningkatan nilai tambah. Substansi pengembangan agribisnis bawang merah diarahkan pada: (a) Pengembangan ketersediaan benih unggul; (b) Pengembangan sentra produksi dan perluasan areal tanam; serta (c) Pengembangan produk olahan.

Bawang merah untuk konsumsi akan memiliki perbedaan-perbedaan dengan produk bawang merah untuk industri bawang goreng. Perbedaan jenis bawang merah tersebut karena perbedaan dalam hal benih, perlakuan dengan teknologinya, usia panen dan harga jual bawang merah. Harga jual bawang merah untuk konsumsi lebih tinggi dari bawang merah untuk industri. Bawang merah untuk industri bawang goreng membutuhkan proses lanjutan dimana perlakuan pascapanen untuk industri bawang goreng meliputi; pengupasan, pengirisan, penggorengan, penirisan, pengeringan, pengemasan (Salingkat, 2017). Pascapanen Perbedaan perlakuan memunculkan perbedaan struktur biaya dan juga efisiensi usahatani bawang merah. Terdapat banyak faktor yang berpengaruh bagi petani dalam hal pengambilan keputusan usahatani bawang merah, meliputi penentuan kombinasi faktor produksi yang efisien agar dapat menghasilkan keuntungan maksimal. Berdasarkan uraian di atas, maka pada penelitian ini membahas mengenai kajian lebih jauh mengenai usahatani bawang merah dalam hal analisis faktor-faktor produksi, struktur biaya serta efisiensi usaha tani bawang merah berdasarkan tujuan pasar untuk konsumsi dan untuk industri. Dimana penelitan analisis faktorfaktor tersebut belum pernah diteliti di Kecamatan Majalengka terutaman pada bidang usaha tani bawang merah. Penelitian ini perlu dilakukan untuk menentukan tujuan pasar yang sesuai dengan produk usaha tani bawang merah. Sehingga diperoleh faktor-faktor produksi, struktur biaya serta efisiensi usaha tani bawang merah berdasarkan tujuan pasar yang efektif dan efisien. Penelitian ini diharapkan dapat memberikan gambaran kepada masyarakat maupun pemerintah daerah dalam pengembangan usaha tani bawang merah yang efisien dan sesuai dengan keadaan daerahnya. 


\section{METODE PENELITIAN}

\section{Lokasi Penelitian}

Penelitian dilakukan di Kecamatan Majalengka, Kabupaten Majalengka, Provinsi Jawa Barat, Indonesia. Dipilih secara simple random sampling karena kecamatan tersebut menerapkan penanaman bawang merah dengan dua varietas yaitu penanaman bawang merah tujuan konsumsi dan tujuan industri bawang goreng. Kabupaten Majalengka merupakan salah satu sentra dan pengembangan produksi bawang merah di Jawa Barat juga sering bekerjasama dengan Balai Benih Hortikultura terutama dalam permohonan pemurnian varietas benih bawang merah. Selain itu, Kecamatan Majalengka, Kabupaten Majalengka juga merupakan salah satu kawasan pembangunan kawasan hortikultura seiring dengan program Pemerintah dalam Program Pengembangan Kawasan Hortikultura Terintegrasi dengan Pendampingan Intensif.

\section{Teknik Penarikan Sampel}

Teknik penarikan sampel yang dilaksanakan pada penelitian ini yaitu proporsional random sampling (Sirait et al., 2020), berdasarkan tujuan pasar dalam usahatani bawang merah antara untuk konsumsi atau untuk industri bawang goreng di Kecamatan Majalengka Kabupaten Majalengka. Selanjutnya untuk mengetahui ukuran sampel yang akan digunakan sebagai responden dihitung dengan menggunakan rumus Slovin sebagai berikut (Adam, 2020) :

$$
n=\frac{N}{N(d)^{2}+1}
$$

Keterangan:

$\mathrm{n}$ : Ukuran sampel

$\mathrm{N}$ : Ukuran populasi

$d^{2}$ : Nilai presisi 90 persen atau signifikan 0,10

Menggunakan rumus di atas maka diperoleh jumlah sampel 82 orang dari populasi petani bawang merah sebanyak 463 orang. Jumlah anggota sampel bertingkat (berstrata) dilakukan dengan cara pengambilan sampel secara proportional random sampling yaitu menggunakan rumus alokasi proportional (Yadava and Singh, 1984):

$$
\mathrm{ni}=\frac{\mathrm{N}_{\mathrm{i}}}{\mathrm{N}} \times \mathrm{n}
$$

Dimana :

$\mathrm{ni}=$ jumlah anggota sampel menurut stratum,

$\mathrm{n}=$ jumlah anggota sampel seluruhnya

$\mathrm{Ni}=$ jumlah anggota populasi menurut stratum

$\mathrm{N}=$ jumlah anggota populasi seluruhnya

\section{Sehingga :}

$\mathrm{n}_{1}=\frac{265}{463} \times 82=46,90 \approx 47$

$\mathrm{n}_{2}=\frac{198}{463} \times 82=35,06 \approx 35$

$\mathrm{n}_{1}=$ jumlah anggota sampel petani bawang merah untuk konsumsi seluruhnya 
$\mathrm{n}_{2}=$ jumlah anggota sampel petani bawang merah untuk industri bawang goreng seluruhnya.

\section{Biaya}

Pengeluaran yang dikeluarkan oleh petani dalam satu kali masa tanam terdiri dari biaya tetap dan biaya variabel. Biaya tetap (fixed cost) diartikan sebagai biaya yang dikeluarkan oleh petani yang tidak tergantung pada besarnya output yang dihasilkan. Biaya variabel (variabel cost) diartikan sebagai biaya yang besar kecilnya dipengaruhi oleh output yang dihasilkan. Kedua biaya tersebut jika dijumlahkan akan menghasilkan biaya total (Yoon, and Naadimuthu, 1994):

$$
\mathrm{TC}=\mathrm{FC}+\mathrm{VC}
$$

Dimana:

TC : Total cost

FC : Fixed cost

VC : Variabel cost

\section{Pendapatan}

Penerimaan yang diperoleh petani merupakan hasil produksi dikalikan dengan harga produk yang diterima petani. Sedangkan struktur penerimaan petani adalah hasil pengurangan total penerimaan dengan jumlah biaya yang dikeluarkan oleh petani dalam satu kali masa tanam. Untuk menghitung jumlah pendapatan petani digunakan rumus (Noer et al., 2020; Kemala, 2020):

$$
\pi=\mathrm{TR}-\mathrm{TC}
$$

Dimana:

$\pi \quad$ : Pendapatan petani

TR : Total Revenue (total penerimaan)

TC : Total Cost (total biaya)

Analisis usahatani bawang merah di Kabupaten Majalengka digunakan R/C Ratio (Revenue Cost Ratio) untuk mengetahui perbandingan tingkat keuntungan dan biaya usahatani.

$$
\mathrm{R} / \mathrm{C}=\frac{\text { Revenue }}{\text { Cost }}
$$

Jika R/C > 1 maka dapat dikatakan usahatani menguntungkan, sedangkan

$\mathrm{R} / \mathrm{C}<1$ usahatani dikatakan merugikan karena biaya yang dikeluarkan lebih besar dari penerimaan yang diperoleh (Sajari, 2017).

\section{Faktor yang mempengaruhi Produksi Bawang Merah}

Metode yang digunakan untuk menduga fungsi produksi Cobb-Douglas adalah metode stochastic frontier. Cobb-Douglas yaitu fungsi atau persamaan yang melibatkan dua atau lebih variabel yaitu dependen $(\mathrm{Y})$ dan independen $(\mathrm{X})$. Fungsi produksi Cobb-Douglas yang digunakan dalam penelitian ini dirumuskan pada persamaan berikut (Nurjati et al., 2018):

$$
Y=a X_{1}^{b 1} X_{2}^{b 2} \ldots X_{i}^{b i} \ldots X_{n}^{b n} . . e^{u}
$$

Untuk memudahkan pendugaan dinyatakan dengan mengubah bentuk linier berganda setelah melogaritmakan persamaan-persamaan tersebut (Fadwiwati et al., 2016; Nurjati et al., 2018): 


$$
\log Y=\log a+b_{1} \log X_{1}+b_{2} \log X_{2}+\ldots+b_{i} \log X_{i}+u \log e
$$

Keterangan :

$$
\begin{array}{ll}
\mathrm{Y} & : \text { Variabel dependen/Hasil Produksi bawang merah } \\
\mathrm{X}_{1}, \mathrm{X}_{2}, . . \mathrm{Xi} & : \text { Variabel independen/faktor-faktor produksi } \\
\mathrm{U} & : \text { kesalahan } \\
\mathrm{e} & : \text { Logaritma natural } \\
\text { a.b } & : \text { Besaran yang akan diduga } \\
\text { (a: intercept/perpotongan, b: elastisitas produksi) }
\end{array}
$$

Analisis efisiensi teknis menggunakan dengan pendekatan fungsi produksi Cobb-Douglas diatas. Fungsi produksi usahatani bawang merah yang telah dispesifikasi dengan fungsi produksi CobbDouglas dan diestimasi didefinisikan sebagai berikut (Fadwiwati et al., 2016; Nurjati et al., 2018):

$$
\operatorname{Ln} Y=\ln a+\beta_{1} \ln X_{1}+\beta_{2} \ln X_{2}+\beta_{3} \ln X_{3}+B_{4} \ln X_{4}+\beta_{5} \ln X_{5}+\beta_{6} \ln X_{6}+u
$$

Dimana:

$Y \quad$ : jumlah produksi bawang merah yang dihasilkan $(\mathrm{Kg})$.

$\mathrm{X}_{1}$ : luas lahan yang digunakan dalam satu kali masa tanam. $\left(\mathrm{m}^{2}\right)$

$\mathrm{X}_{2}$ : jumlah benih yang digunakan dalam satu kali masa tanam $(\mathrm{Kg})$

$\mathrm{X}_{3}$ : jumlah pupuk NPK yang digunakan dalam satu kali masa tanam $(\mathrm{Kg})$.

$\mathrm{X}_{4} \quad$ : jumlah pupuk Organik yang digunakan dalam satu kali masa tanam $(\mathrm{Kg})$.

$\mathrm{X}_{5}$ : jumlah seluruh pestisida yang digunakan dalam satu kali masa tanam $(\mathrm{L})$.

$\mathrm{X}_{6}$ : Tenaga Kerja (HOK)

$\beta_{0}-\beta_{5}:$ Koefisien regresi

u : kesalahan (disturbance term)

Data yang terkumpul kemudian ditabulasi dan dilakukan analisis deskriptif. Untuk analisis faktorfaktor yang mempengaruhi produksi bawang merah yang mengikuti model fungsi produksi CobbDouglas yang ditransformasikan ke dalam bentuk double logaritma natural (In), sehingga merupakan bentuk regresi linear berganda yang kemudian dianalisis.

\section{HASIL DAN PEMBAHASAN}

\section{Struktur Biaya Usahatani Bawang Merah}

Petani bawang merah umumnya selain menggunakan tenaga kerja keluarga juga menggunakan tenaga kerja luar keluarga, terutama pada petani yang memiliki lahan luas. Upah yang di berlaku dilokasi penelitian Rp.80.000/ hari untuk pria dan Rp.50.000/ hari untuk wanita. Biaya penyusutan alat diperhitungkan dari nilai harga peralatan seperti cangkul, kored, parang, garpu,sprayer dan lantai jemur, biaya pajak PBB, biaya pengadaan air dan biaya sewa lahan. Analisis rata-rata penggunaan biaya produksi bawang merah untuk tujuan konsumsi dan tujuan industri bawang goreng menggunakan persamaan (1). Berdasarkan hasil analisis disajadikan pada Tabel 1. 
Tabel 1. Biaya Rata-rata Usahatani Bawang Merah per Hektar Kabupaten Majalengka

\begin{tabular}{|c|c|c|c|c|}
\hline \multirow{2}{*}{$\begin{array}{l}\text { Biaya } \\
\text { I. } \quad \text { Benih/Bibit }\end{array}$} & \multicolumn{2}{|c|}{$\begin{array}{l}\text { Rata-rata Bawang Merah } \\
\text { Industri Bawang Goreng }\end{array}$} & \multicolumn{2}{|c|}{ Rata-rata Bawang Merah Konsumsi } \\
\hline & $\mathrm{Kg}$ & $\mathrm{Rp}$ & $\mathrm{Kg}$ & $\mathrm{Rp}$ \\
\hline Sumenep & 465,62 & 13.548 .300 & & \\
\hline Bima Brebes & & & $1.025,69$ & $30.870 .148,94$ \\
\hline Jumlah Biaya Bibit & & 13.548 .300 & & $30.870 .148,94$ \\
\hline II. Pupuk & $\mathrm{Kg} / \mathrm{Lt}$ & $\mathrm{Rp}$ & $\mathrm{Kg}$ & $\mathrm{Rp}$ \\
\hline Pupuk NPK & 119,42 & $1.176 .222,86$ & 136,86 & $1.291 .846,81$ \\
\hline Pupuk Organik & 8,91 & $4.455,57$ & 8,48 & $4.241,1$ \\
\hline Pupuk ZA & 86,72 & $173.434,9$ & 267,34 & $534.672,34$ \\
\hline Pupuk TSP & 65,58 & $226.518,57$ & 144,60 & $482.129,36$ \\
\hline Pupuk Urea & 151,19 & $412.245,7$ & 159,33 & $387.729,79$ \\
\hline Pupuk KCL & 87,04 & $359.988,6$ & 174,51 & $767.902,13$ \\
\hline Pestisida & 256,64 & $799.428,6$ & 473,46 & $795.319,15$ \\
\hline Jumlah Biaya Pupuk & & $3.152 .294,71$ & & $4.263 .840,64$ \\
\hline III. Tenaga Kerja & Hok & $\mathrm{Rp}$ & Hok & $\mathrm{Rp}$ \\
\hline Pengelolaan Benih & 2,02 & $159.787,2$ & 2,29 & $169.714,30$ \\
\hline Pengolahan lahan & 2,13 & $164.468,1$ & 2,41 & $168.285,70$ \\
\hline Penanaman & 10,04 & $499.574,5$ & 5,74 & 296.000 \\
\hline Pemupukan & 2,98 & $218.510,6$ & 2,19 & 146.000 \\
\hline Penyulaman & 3,84 & $252.553,2$ & 2,23 & 130.000 \\
\hline Pengendalian Hama & 2,64 & $184.130,4$ & 1,82 & $982.85,7$ \\
\hline Panen & 11 & $540.212,8$ & 7,37 & $350.571,40$ \\
\hline Pengambilan hasil Panen & 5,52 & 253829,8 & 2,94 & 142.000 \\
\hline Pembersihan & 2,87 & $168.936,2$ & 2,81 & $124.571,40$ \\
\hline Penjemuran & 3,75 & $208.723,4$ & 4,91 & $231.142,90$ \\
\hline Pengemasan hasil & 5,56 & 267.234 & 2,1 & $88.571,40$ \\
\hline Pengangkutan ke Pasar & 1,4 & $68.085,11$ & 1,1 & $571.42,9$ \\
\hline $\begin{array}{l}\text { Jumlah Biaya Tenaga } \\
\text { Kerja }\end{array}$ & & $3.123 .142,9$ & & $2.178 .297,9$ \\
\hline IV. Biaya Tetap & $\mathrm{Ha} / \mathrm{Jumlah}$ & $\mathrm{Rp}$ & Ha/Jumlah & $\mathrm{Rp}$ \\
\hline Sewa Lahan & 1,1 & 2.560 .000 & 1,07 & $6.034 .893,62$ \\
\hline Pajak PBB & 0,54 & $78.557,14$ & 0,63 & $82.468,09$ \\
\hline Pegadaan Air & 0,71 & $105.985,7$ & 0,639 & 102.638 \\
\hline Penyusutan Alat & 13,7 & $579.454,2$ & 16,7 & $711.249,7$ \\
\hline Total Biaya Tetap & & $23.116 .674,71$ & & $44.242 .628,19$ \\
\hline
\end{tabular}

Biaya usahatani bawang merah untuk konsumsi maupun tujuan industri bawang goreng yaitu yang dikeluarkan oleh petani responden, semua pengeluaran yang dinyatakan dengan uang yang diperlukan untuk menghasilkan sesuatu produk dalam suatu periode produksi. Biaya usahatani bawang merah terdiri dari biaya tetap dan biaya variabel. Biaya tetap merupakan biaya yang besar kecilnya tidak dipengaruhi oleh besar kecilnya produksi sedangkan untuk biaya variabel adalah biaya yang besar kecilnya dipengaruhi oleh besar kecilnya produksi dan sifatnya habis dalam satu kali proses produksi.

Berdasarkan hasil pada Tabel 1, biaya tetap usahatani bawang merah tujuan untuk konsumsi dan industri bawang goreng tentunya berbeda dengan biaya tetap usahatani bawang 
merah untuk tujuan industri bawang goreng sebesar Rp. 23.116.674,71 dan untuk total jumlah biaya tetap usahatani bawang merah tujuan konsumsi yaitu sebesar Rp. 44.242.628,19, biaya tetap usahatani bawang merah sangat dipengaruhi oleh biaya pembelian bibit (benih), pupuk yang digunakan dan tenaga kerja yang digunakan serta biaya sewa lahan.

\section{Pendapatan}

Penerimaan merupakan refleksi dari kinerja produksi dan dinamika harga, artinya besarnya penerimaan ditentukan oleh dua aspek yaitu aspek produksi dan aspek harga, dengan kata lain penerimaan bisa meningkat apabila produksi meningkat walaupun harga tetap, atau harga meningkat dan produksi teta atau kedua aspek tersebut meningkat. Pada satu musim tanam, panen bawang merah bisa mencapai 3-5 Ton/ Ha dengan tingkat harga yang bervariasi tergantung pada kondisi pasar dan kulaitas hasil. Untuk lebih jelasnya hasil penerimaan hasil usahatani bawang merah dengan menggunakan persamaan (2) dan (3) disajikan pada Tabel 2 sebagai berikut.

Tabel 2. Penerimaan Rata-rata pada Usahatani Bawang Merah per Hektar Kabupaten Majalengka

\begin{tabular}{lcr}
\hline \multicolumn{1}{c}{ Uraian } & $\begin{array}{c}\text { Bawang Merah } \\
\text { Industri Bawang Goreng }\end{array}$ & \multicolumn{1}{c}{$\begin{array}{c}\text { Bawang Merah } \\
\text { Konsumsi }\end{array}$} \\
\hline Produksi (Kg) & $3.396,90$ & $5.094,60$ \\
Harga (Rp/Kg) & $8.365,70$ & $9.914,90$ \\
Penerimaan (Rp) & $27.264 .557,14$ & $51.767 .510,64$ \\
\hline
\end{tabular}

Berdasarkan hasil analisis pada Tabel 2, harga sangat ditentukan oleh berbagai faktor, antara lain kualitas bawang merah yang dihasilkan, tujuan penjulan dan ketersediaan bawang merah di pasar. Kelemahan mekanisme harga produk pertanian adalah harga yang jatuh saat panen raya, karena supply terlalu banyak. Rata-rata harga bawang merah di tingkat petani sebesar Rp. 9.914,90/Kg untuk tujuan konsumsi sedangkan untuk rata-rata harga bawang untuk tujuan industri bawang goreng dengan harga Rp. 8.365,70/Kg. Rata-rata hasil produksi bawang merah untuk tujuan konsumsi yaitu 5.094,60 Kg per hektar sedangkan untuk bawang merah tujuan industri bawang goreng dengan jumlah rata-rata hasil produksinya sebesar 3.396,90 kg per hektar. Dari harga dan produksi maka usahatani bawang merah tujuan konsumsi mendapatkan penerimaan sebesar Rp. 51.767.510,64 dan untuk usahatani bawang merah tujuan industri bawang goreng mendapatkan penerimaan sebesar Rp. 27.264.557,14. Selanjutnya melakukan analisis usahatani bawang merah per hektar di Majalengka yang diberikan pada Tabel 3.

Tabel 3. Analisis Usahatani Bawang Merah Per hektar di Majalengka

\begin{tabular}{lcc}
\hline \multicolumn{1}{c}{ Uraian } & $\begin{array}{c}\text { Bawang Merah } \\
\text { Industri Bawang Goreng }\end{array}$ & $\begin{array}{c}\text { Bawang Merah } \\
\text { Konsumsi }\end{array}$ \\
\hline Biaya (Rp) & $23.116 .674,71$ & $44.242 .628,19$ \\
Penerimaan (Rp) & $27.264 .557,14$ & $51.767 .510,64$ \\
Pendapatan (Rp) & $4.147 .882,43$ & $7.524 .882,45$ \\
R/C & 1,25 & 1,30 \\
\hline
\end{tabular}

Indikator lainnya yang biasa digunakan untuk menilai kinerja usahatani adalah $\mathrm{R} / \mathrm{C}$, yaitu rasio antara penerimaan dan biaya dikeluarkan. Semakin besar R/C maka usahatani tersebut 
semakin menguntungkan dan layak untuk digunakan. Berdasarkan hasil analisi usahatani bawang merah per hektar di Majalengka pada Tabel 3, R/C rata-rata usahatani bawang merah tujuan konsumsi adalah 1,30 sedangkan untuk usahatani bawang merah tujuan industri bawang goreng dengan nilai $R / C$ 1.25. Dari nilai $R / C>1$ di atas maka usahatani bawang merah untuk tujuan konsumsi dan tujuan industri bawang goreng di kabupaten Majalengka dikatakan layak.

\section{Analisis Fungsi Produksi Stochastic Frontier Bawang Merah}

Fungsi produksi yang digunakan dalam penelitian ini adalah dengan model fungsi produksi stochastic frontier dengan metode Ordinary Least Square (OLS) dan Maximum Likelihood Estimators (MLE). Model fungsi produksi stochastic frontier Cobb-Douglass pada penelitian ini dibangun dengan sepuluh variable bebas dan satu variable terikat. Variable bebas yang digunakan dalam penelitian ini yaitu luas lahan $\left(X_{1}\right)$, jumlah bibit $\left(X_{2}\right)$, pupuk NPK $\left(X_{3}\right)$, pupuk organik $\left(X_{4}\right)$, pupuk ZA $\left(X_{5}\right)$, pupuk $\operatorname{TSP}\left(X_{6}\right)$, pupuk urea $\left(X_{7}\right)$, pupuk KCL $\left(X_{8}\right)$, pestisida $\left(X_{9}\right)$ dan tenaga kerja $\left(X_{10}\right)$. Sedangkan untuk variabel terikat adalah produksi bawang merah $(Y)$. Ringkasan data pendugaan fungsi produksi usahatani bawang merah tujuan industry dan tujuan Konsumsi diberikan pada Tabel 4 dan 5.

Tabel 4. Ringkasan Data Pendugaan Fungsi Produksi Usahatani Bawang Merah Tujuan Industri Bawang Goreng

\begin{tabular}{lcc}
\hline Variabel & Simbol & Rata-rata \\
\hline Produksi & $\mathrm{Y}$ & $3.396,9$ \\
Luas Lahan & $\mathrm{X}_{1}$ & 0,66 \\
Jumlah Bibit & $\mathrm{X}_{2}$ & 465,62 \\
Pupuk NPK & $\mathrm{X}_{3}$ & 119,42 \\
Pupuk Organik & $\mathrm{X}_{4}$ & 8,91 \\
Pupuk Za & $\mathrm{X}_{5}$ & 86,72 \\
Pupuk TSP & $\mathrm{X}_{6}$ & 65,58 \\
Pupuk Urea & $\mathrm{X}_{7}$ & 151,19 \\
Pupuk KCL & $\mathrm{X}_{8}$ & 87,04 \\
Pestisida & $\mathrm{X}_{9}$ & 256,64 \\
Tenaga Kerja & $\mathrm{X}_{10}$ & 52,5 \\
\hline
\end{tabular}

Tabel 5. Ringkasan data pendugaan fungsi produksi usahatani bawang merah tujuan Konsumsi

\begin{tabular}{lcc}
\hline Variabel & Simbol & Rata-rata \\
\hline Produksi & $\mathrm{Y}$ & 5094,6 \\
Luas Lahan & $\mathrm{X}_{1}$ & 0,91 \\
Jumlah Bibit & $\mathrm{X}_{2}$ & $1.025,7$ \\
Pupuk NPK & $\mathrm{X}_{3}$ & 136,86 \\
Pupuk Organik & $\mathrm{X}_{4}$ & 8,48 \\
Pupuk Za & $\mathrm{X}_{5}$ & 267,34 \\
Pupuk TSP & $\mathrm{X}_{6}$ & 144,6 \\
Pupuk Urea & $\mathrm{X}_{7}$ & 159,33 \\
Pupuk KCL & $\mathrm{X}_{8}$ & 174,51 \\
Pestisida & $\mathrm{X}_{9}$ & 473,46 \\
Tenaga Kerja & $\mathrm{X}_{10}$ & 37 \\
\hline
\end{tabular}


Berdasarkan pada Tabel 4 dan 5 menunjukkan rata-rata produksi bawang merah tujuan industri bawang goreng sebesar 3.396,9 ton yang dihasilkan dari lahan dengan luas rata-rata 0,66 hektar. Selanjutnya, rata-rata penggunaan jumlah pupuk adalah 518,86 kilogram. Rata-rata jumlah input bibit yang digunakan adalah 465,62 kilogram, rata-rata penggunaan tenaga kerja adalah 52,5 HOK dan pestisida 256,64 liter. Sedangkan untuk usahatani bawang merah tujuan konsumsi ratarata produksi sebesar 5094,60 ton yang dihasilkan dari luas rata-rata 0,91 hektar dan rata-rata pengunaan pupuk yaitu sebesar 891,12 kilogram. Rata-rata pengunaan bibit 1.025,7 kilogram, pengunaan tenaga kerja yaitu $37 \mathrm{HOK}$ dan penggunaan pestisida rata-rata 473,46 liter.

Langkah selanjutnya adalah menganalisi pendugaan fungsi produksi dengan metode Ordinary Least Square (OLS). Pengujian ini merupakan pengujian penyimpangan asumsi klasik untuk mengetahui apakah terdapat pelanggaran terhadap asumsi-asumsi klasik yang terkait dengan galat. Jika dalam pengujian yang dilakukan tidak terdapat penyimpangan atau tidak terdapat asumsi klasik yang dilanggar, maka model yang digunakan dapat diuji lebih lanjut dengan metode Maximum Likelihood Estimators (MLE) untuk melihat signifikansi model dan variabelnya. Pengujian asumsi klasik yang dilakukan meliputi uji multikolinearitas, uji heteroskedastisitas, dan uji normalitas. Pengujian yang dilakukan menggunakan software SPSS. Tabel 6 menunjukkan hasil dugaan fungsi produksi stochastic frontier dengan metode Ordinary Least Square (OLS) dan metode Maximum Likelihood Estimators (MLE) usahatani bawang merah tujuan industri bawang goreng.

Tabel 6. Hasil Usatani Tujuan Industri Bawang Goreng Dugaan Fungsi Produksi Stochastic Frontier dengan OLS dan MLE.

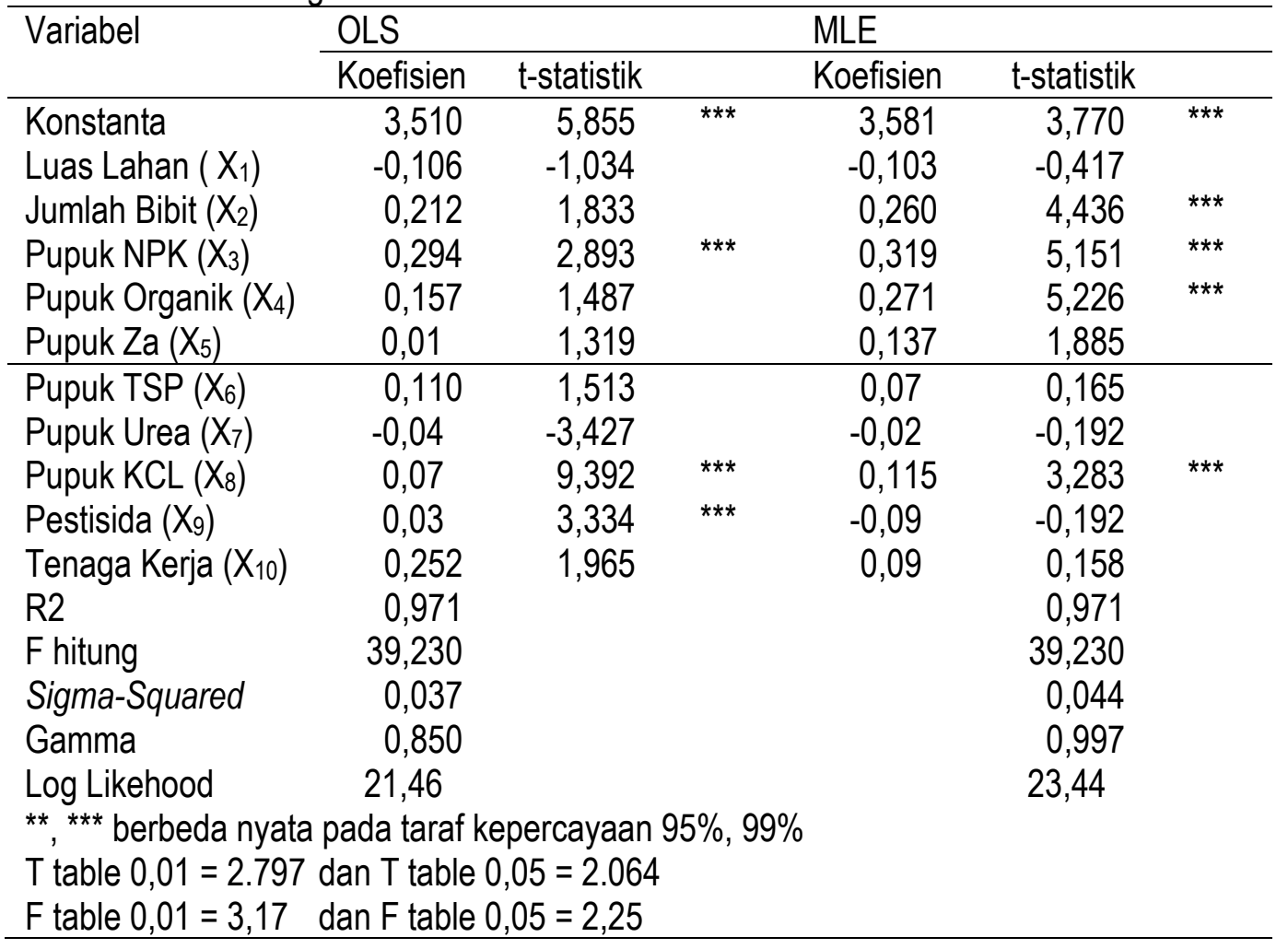


Berdasarkan hasil di atas diperoleh Stochastik Frontier Analysis (SFA) dari persamaan (4) dan (5), produksi bawang merah tujuan Industri bawang goring disajikan sebegai berikut:

$\operatorname{Ln} Y=\ln \beta 0+\beta 1 \ln X_{1}+\beta 2 \ln X_{1}+\beta 3 \ln X_{3}+\beta 4 \ln X_{4}+\beta 5 \ln X_{5}+\beta 6 \ln X_{6}+\beta 7 \ln X_{7}+\beta 8 \ln X_{8}+$ $\beta 9 \ln X_{9}+\beta 10 \ln X_{10}$

Sehingga:

$\operatorname{Ln} Y=3,581-(0,103) X_{1}+0,260 X_{2}+0,319 X_{3}+0,271 X_{4}+0,137 X_{5}+0.07 X_{6}-(0,02) X_{7}+0,15$ $X_{8}-(0,09) X_{9}+0,09 X_{10}$

Dari Tabel 6, dapat diketahui bahwa dari sepuluh variabel independen terdapat empat variabel yang berpengaruh signifikan pada taraf kepercayaan $99 \%$ atau $\alpha=0,01$, yaitu Jumlah Bibit, pupuk NPK, pupuk organik dan pupuk KCL. Hasil estimasi stochastic frontier dengan menggunakan pendekatan MLE lebih baik dibandingkan dengan pendekatan OLS, karena pada pendekatan MLE menunjukan estimasi gamma serta nilai sigma square dan Log Likehood yang lebih tinggi. Nilai gamma menunjukan variasi produksi bawang merah akibat efesiensi teknis usahatani bawang merah dan nilai sigma square menunjukan estimasi variasi dari kesalahan atau error term akibat inefisiensi teknis.

Secara garis besar variabel yang pengaruh untuk usahatani bawang merah tujuan industri bawang goreng dengan menggunakan pendekatan MLE tersebut sama dengan pendekatan OLS, namun dengan pendekatan MLE taraf kepercayaan yang digunakan lebih tinggi. Pada pendekatan MLE juga menunjukan nilai sigma square dan Log Likelihood yang lebih tinggi disbanding dengan pendekatan OLS. Oleh karena itu pendakatan MLE dipilih untuk mengetahui faktor-faktor yang berpengaruh pada usahatani bawang merah tujuan industri bawang goreng. Selanjutnya Hasil usatani bawang merah tujuan konsumsi dugaan fungsi produksi stochastic frontier dengan OLS dan MLE diberikan pada Tabel 7.

Tabel 7. Hasil Usatani Bawang Merah Tujuan Konsumsi Dugaan Fungsi Produksi Stochastic Frontier dengan OLS dan MLE.

\begin{tabular}{lcccccc}
\hline Variabel & \multicolumn{5}{c}{ OLS } & \multicolumn{5}{c}{ KLE } \\
\cline { 2 - 7 } & Koefisien & t-statistik & & Koefisien & t-statistik & \\
\hline Konstanta & 4,702 & 10,16 & $* * *$ & 4,758 & 14,04 & $* * *$ \\
Luas Lahan $\left(X_{1}\right)$ & 0,189 & 2,151 & $* *$ & 0,203 & 3,001 & $* * *$ \\
Jumlah Bibit $\left(X_{2}\right)$ & 0,05 & 0,176 & & 0,03 & 0,445 & \\
Pupuk NPK $\left(X_{3}\right)$ & 0,02 & 0,345 & & 0,01 & 0,235 & \\
Pupuk Organik $\left(X_{4}\right)$ & 0,05 & 0,583 & & 0,03 & 0,423 & \\
Pupuk Za $\left(X_{5}\right)$ & 0,106 & 1,460 & & 0,120 & 1,947 & $* *$ \\
Pupuk TSP $\left(X_{6}\right)$ & 0,239 & 2,706 & $* *$ & 0,248 & 3,494 & $* * *$ \\
Pupuk Urea $\left(X_{7}\right)$ & 0,189 & 2,168 & $* *$ & 0,195 & 2,922 & $* * *$ \\
Pupuk KCL $\left(X_{8}\right)$ & $-0,007$ & $-0,08$ & & 0,02 & 0,214 & \\
Pestisida $\left(X_{9}\right)$ & 0,186 & 2,224 & $* *$ & 0,180 & 2,577 & $*$ \\
Tenaga Kerja $\left(X_{10}\right)$ & $-0,08$ & $-1,024$ & & $-0,06$ & $-0,891$ & \\
R2 & 0,635 & & & 0,635 & & \\
F hitung & 8,999 & & & 8,999 & & \\
\hline
\end{tabular}




\begin{tabular}{|c|c|c|c|c|}
\hline \multirow[t]{2}{*}{ Variabel } & OLS & & \multicolumn{2}{|l|}{ MLE } \\
\hline & \multirow{2}{*}{\multicolumn{2}{|c|}{ Koefisien }} & Koefisien & t-statistik \\
\hline Sigma-Squared & & & 0,026 & \\
\hline Gamma & 0,570 & & \multicolumn{2}{|l|}{0,745} \\
\hline Log Likehood & \multicolumn{2}{|l|}{34,55} & \multicolumn{2}{|l|}{35,22} \\
\hline \multicolumn{5}{|c|}{ **, ${ }^{* * *}$ berbeda nyata pada taraf kepercayaan $95 \%, 99 \%$} \\
\hline \multicolumn{5}{|c|}{$\begin{array}{l}\text { T tabel } 0,01=2,719 \text { dan Ttabel } 0,05=2,028 \\
F \text { tabel } 0.01=2.86 \text { dan } F \text { tabel } 0.05=2.11\end{array}$} \\
\hline
\end{tabular}

Berdasarkan hasil di atas diperoleh persamaan Stochastik Frontier Analysis (SFA) dari persamaan (4) dan (5), produksi bawang merah konsumsi sebegai berikut:

$\operatorname{Ln} Y=\ln \beta 0+\beta 1 \ln X_{1}+\beta 2 \ln X_{1}+\beta 3 \ln X_{3}+\beta 4 \ln X_{4}+\beta 5 \ln X_{5}+\beta 6 \ln X_{6}+\beta 7 \ln X_{7}+\beta 8 \ln X_{8}+$ $\beta 9 \ln X_{9}+\beta 10 \ln X_{10}$

Sehingga:

$$
\begin{aligned}
\operatorname{Ln} Y= & 4,758+0,203 X_{1}+0,03 X_{2}+0,01 X_{3}+0,03 X_{4}+0,120 X_{5}+0,248 X_{6}+0,195 X_{7}+0,02 X_{8} \\
& +0,180 X_{9}+(0,06) X_{10}
\end{aligned}
$$

Dari Tabel 7, dapat diketahui bahwa dari sepuluh variabel independen terdapat empat variabel yang berpengaruh signifikan pada taraf kepercayaan $99 \%$ atau $\alpha=0,01$, yaitu luas lahan, pupuk TSP, pupuk urea dan pestisida dan berpengaruh signifikan pada taraf kepercayaan $95 \%$ atau $a=0,05$ yaitu pupuk ZA. Hasil estimasi stochastic frontier dengan menggunakan pendekatan MLE lebih baik dibandingkan dengan pendekatan OLS,karena pada pendekatan MLE menunjukkan estimasi gamma serta nilai sigma square dan Log Likehood yang lebih tinggi. Nilai gamma menunjukkan variasi produksi bawang merah akibat efesiensi teknis usahatani bawang merah dan nilai sigma square menunjukkan estimasi variasi dari kesalahan atau error term akibat inefisiensi teknis.

\section{SIMPULAN}

Struktur biaya Usahatani bawang merah tujuan industri bawang goreng dan konsumsi layak diusahakan bila dilihat dari $\mathrm{R} / \mathrm{C}$ rasio rata-rata usahatani bawang goreng dengan nilai 1,25 dan untuk usahatani bawang merah tujuan konsumsi dengan nilai sebesar 1,30 , dengan $R / C>1$. Faktor produksi yang membutuhkan biaya terbesar untuk usahatani bawang merah tujuan industri bawang goreng yaitu biaya bibit/benih dengan nilai sebesar Rp.13.548.300 dan biaya terbesar yang digunakan usahatani bawang merah tujuan konsumsi yaitu biaya benih/bibit sebesar Rp.30.870.148,94. Hal ini disebabkan kebutuhan bibit untuk luasan satu hektar, harga bibit yang cukup tinggi karena keterbatasaan jumlah bibit/benih yang dibutuhkan sehingga harga bibit meningkat dan faktor kemaurau juga pengaruh terhadap keterbatasan bibit yang dibutuhkan. Sedangkan faktor-faktor yang berpengaruh terhadap produksi usahatani bawang merah dengan tujuan industri bawang goreng adalah Jumlah bibit, pupuk NPK, pupuk organic, pupuk KCL dan pupuk ZA. Untuk usahatani bawang merah tujuan konsumsi Faktor yang berpengaruh terhadap produksi bawang merah menunjukkan luas lahan, pupuk, pupuk urea dan pestisida.. 


\section{REFERENSI}

Adam, A. M. (2020). Sample size determination in survey research. Journal of Scientific Research and Reports, 26(5), 90-97.

Alfarizy, A., Setiawan, M. A. \& Kalfin. (2021). Production Development Strategy on Corn (Zea Mays) Commodity in Banten Province Using Process Hierarchy Analysis Method. International Journal of Research in Community Services, 2(1), 18-23.

Apriani, L.N. (2011). Analisis Efisiensi Teknis dan Pendapatan Usahatani Bawang Merah (Studi Kasus: Desa Sukasari Kaler Kecamatan Argapura Kabupaten Majalengka Provinsi Jawa Barat [tesis]. Bogor (ID): Institut Pertanian Bogor.

Fadwiwati, A. Y., Hartoyo, S., Kuncoro, S. U., \& Rusastra, I. W. (2016). Analisis Efisiensi Teknis, Efisiensi Alokatif, Dan Efisiensi Ekonomi Usahatani Jagung Berdasarkan Varietas Di Provinsi Gorontalo. Jurnal Agro Ekonomi, 32(1), 1-12.

Fauzan M. (2016). Pendapatan, risiko, dan efisiensi ekonomi usahatani bawang merah di Kabupaten Bantul. Jurnal Agraris. 2(2):107-117.

Kalfin, S., Supian, S., Mamat, M., Muljana, F., \& Bon, A. T. (2021). Analysis of Agropolitan Area Planning Based on Natural Disaster Mitigation in West Muna Regency, Southeast Sulawesi, Indonesia. In Proceedings of the International Conference on Industrial Engineering and Operations Management (pp. 3592-3601).

Kemala, S. (2020). Simulasi usaha tani jarak pagar (Jatropha curcas L.). Jurnal Penelitian Tanaman Industri, 12(3), 87-97.

Noer, S. R., Zakaria, W. A., \& Murniati, K. (2020). Analisis efisiensi produksi usahatani padi ladang di Kecamatan Sidomulyo Kabupaten Lampung Selatan. Jurnal IImu IImu Agribisnis: Journal of Agribusiness Science, 6(1), 17-24.

Nurjati, E., Fahmi, I., \& Jahroh, S. (2018). Analisis Efisiensi Produksi Bawang Merah di Kabupaten Pati dengan Fungsi Produksi Frontier Stokastik COBB-DOUGLAS. Jurnal Agro Ekonomi, 36(1), 15-29.

Padjung, R., Syam'un, E., Haring, F., Mantja, K., Kasim, N., \& Suni, Y. (2020). Weeds diversity and the production of shallot (Allium ascalonicum L.) due to the application of azolla fertilizers and oxyfluorfen. In IOP Conference Series: Earth and Environmental Science, Vol. 575, No. 1, p. 012121). IOP Publishing.

Rachman, H.P.S., Supriyati, Saptana, B. Rachman. (2004). Efisiensi dan dayasaing usahatani hortikultura. Bogor, Indonesia. Bogor (ID). PSEKP, hlm 50- 82.

Rahmadona, L., \& Fariyanti, A. (2017). Dayasaing Komoditas Bawang Merah di Kabupaten Majalengka, Jawa Barat. Jurnal Hortikultura Indonesia, 8(2), 128-135.

Razzianto, D.A., Suminartika, E. \& Noor, T.I. (2020). Analysis of Structure and Cost Efficiency of Shallot (Allium ascalonicum L.)Farming Based on Market Purposes. International Journal of Advanced Science and Technology, Vol. 29, No. 7, pp. 1549-1555.

Sajari, I. (2017). Analisis Kelayakan Usaha Keripik Pada UD. Mawar di Gampong Batee le Liek Kecamatan Samalanga Kabupaten Bireuen. Jurnal Sains Pertanian, 1(1), 210819.

Salingkat, C. A. (2017). Potensi Pengembangan Usaha Pengolahan Bawang Goreng Lokal Di Kota Palu. Agroland: Jurnal Ilmu-ilmu Pertanian, 24(2), 163-171.

Setiawan, M. A., Kalfin, K., \& Setiawan, P. (2021). Efforts to Improve MSME Commodity Marketing in Tasikmalaya Regency during the Covid-19 Pandemic through Training and Mentoring Programs. International Journal of Research in Community Services, 2(1), 38-43. 
Sirait, H., Karolin, S., Sukono, Kalfin, \& Bon, A.T. (2020). Ratio Estimator for Population Variations Using Additional Information on Simple Random Sampling. Proceedings of the 5th NA International Conference on Industrial Engineering and Operations Management Detroit, Michigan, USA.

Tian, H., Wang, T., Liu, Y., Qiao, X., \& Li, Y. (2020). Computer vision technology in agricultural automation-A review. Information Processing in Agriculture, 7(1), 1-19.

Yadava, S. S., \& Singh, R. (1984). Optimum stratification for allocation proportional to strata totals for simple random sampling scheme. Communications in Statistics-Theory and Methods, 13(22), 2793-2806.

Yoon, K. P., \& Naadimuthu, G. (1994). A Make-or-Buy Decision Analysis Involving Imprecise Data. International Journal of Operations and Production Management, 14(2), 62-69. 